\title{
Uji Akurasi Beberapa Indeks Vegetasi dalam Mengestimasi Kerapatan Hutan Mangrove dengan Citra Sentinel-2A di Taman Nasional Bali Barat
}

\author{
Maulana Ilham Fahmy Alam ${ }^{a^{*}}$, I Wayan Nuarsa ${ }^{a}$, Ni Luh Putu Ria Puspitha ${ }^{a}$ \\ ${ }^{a}$ Program Studi Ilmu Kelautan, Fakultas Kelautan dan Perikanan, Universitas Udayana, Bali, Indonesia \\ *Corresponding author, email:nuarsa@unud.ac.id
}

\section{ARTICLE INFO}

\section{ABSTRACT}

\section{Article history:}

Received: June $3^{\text {th }} 2020$

Received in revised form: July $27^{\text {th }} 2020$

Accepted: August $13^{\text {th }} 2020$

Available online: August $31^{\text {th }} 2020$
Keywords:

Canopy

Hemispherical photography

Vegetation index

Mangrove density

Remote sensing

\begin{abstract}
Vegetation Indices is one of the remote sensing parameters that can be used to estimate the mangrove forest density. The purpose of this study is to determine the vegetation index with the best accuracy to estimate the condition of mangrove density, as well as determine the spatial distribution of mangrove density in the TNBB area. This study uses Sentinel-2A satellite imagery data and five different vegetation indices, namely NDVI, NNIR, EVI, mRE-SR, and vegetation index developed in this study. The method of determining samples in the field uses stratified random and proportional sampling. Data collection of canopy density used hemispherical photography method, which is taking vertical photos with a $180^{\circ}$ angle of view using a camera with a Fish Eye or Wide lens. Data analysis used in this study is regression analysis, coefficient of determination test, model validation test, and paired $\mathrm{t}$ test. From statistical tests conducted on several vegetation indices, the mRE-SR vegetation index value shows the best results on all the accuracy parameters tested. The $\mathrm{R}^{2}$ value was generated by the mRE-SR vegetation index from the relationship between mangrove density results from field measurements with the vegetation index value and the estimated density results shows that the highest values, namely 0.909 and 0.935 . These results show that the mRE-SR vegetation index is the best vegetation index in explaining the variation of mangrove density in the field. The $\mathrm{mRE}-\mathrm{SR}$ vegetation index also has the lowest deviation of the estimated value, with the resulting $\mathrm{SE}$ values in the two linear relationships of 1,592 and 0,999. In addition, the mRE-SR vegetation index has a $\mathrm{P}(\mathrm{T}<=\mathrm{t})$ two-tail value greater than the significance level $(0.05)$, the results means that two values of the tested variables are not significant different. The calculation results show that the total area of mangroves in TNBB is 409.21 ha. From the percentage of density obtained, the mangrove density class was only distributed in the medium and solid density classes.
\end{abstract}

2020 JMRT. All rights reserved.

\section{Pendahuluan}

Hutan mangrove merupakan ekosistem vital yang memegang peranan penting dalam menjaga keseimbangan berbagai siklus terutama di kawasan pesisir (Andriani et al., 2017; Sari dan Rosalina, 2016). Luas kawasan hutan mangrove Indonesia tahun 2015 diperkirakan sebesar 3.489.140,68 ha atau $23 \%$ dari luasan mangrove dunia, sehingga hutan mangrove Indonesia adalah kawasan hutan mangrove terluas yang ada di dunia. Namun dari total luas hutan mangrove di Indonesia diketahui bahwa seluas $1.671 .140,75$ ha $(47,9 \%)$ dalam kondisi baik, sedangkan $1.817 .999,93$ ha $(52,1 \%)$ dalam kondisi rusak (KLHK, 2017).

Ekosistem mangrove di Provisni Bali terdapat di beberapa lokasi dengan keseluruhan area seluas 3067.71 ha, dimana 2177,5 ha $(71 \%)$ berada di dalam kawasan hutan, dan 890,21 ha $(29 \%)$ berada di luar kawasan hutan. Salah satu dari tiga lokasi terluas kawasan hutan mangrove di Bali adalah Taman Nasional Bali Barat (MIC, 2004). Kawasan hutan mangrove yang berada di Taman Nasional Bali Barat (TNBB) merupakan objek konservasi. Walaupun demikian tidak dapat dipungkiri bahwa mangrove di kawasan tersebut juga dapat terancam aktivitas antropogenik yang mempengaruhi kondisi ekosistem hutan mangrove seperti penebangan liar ataupun permasalahan sampah yang terjadi. Pada bulan Februari hingga Oktober 2017 tercatat volume sampah yang mengotori mangrove di kawasan tersebut mencapai 11,1 ton (BROL, 2017). Hal ini dikhawatirkan dapat menutup akar-akar mangrove sehingga mengganggu kondisi ekosistem mangrove di kawasan tersebut. Oleh sebab itu pada tahun 2018 Balai Taman Nasional Bali Barat melakukan kordinasi dengan berbagai pihak sebagai upaya pengendalian sampah di kawasan tersebut (KLHK, 2018). Berdasarkan hasil wawancara lapangan dengan instansi terkait menunjukkan bahwa Balai Taman Nasional Bali Barat belum memiliki data kondisi kerapatan mangrove secara spasial. Selain itu, dari hasil obeservasi lapangan tersebut juga diketahui bahwa dalam beberapa tahun ke depan akan ada Ijin Pengusahaan Pariwisata Alam (IPPA) baru di kawasan mangrove TNBB. Dengan demikian kajian mengenai kondisi 
kerapatan hutan mangrove di kawasan TNBB menjadi sangat penting untuk dilakukan sehingga dapat dijadikan sebagai salah satu bahan pertimbangan dalam membangun kebijakan IPPA tersebut.

Dalam mengestimasi kerapatan ekosistem hutan mangrove dapat dilakukan dengan menggunakan metode penginderaan jauh, sehingga lebih cepat dan efisien (Kawamuna et al., 2017). Selama ini, pemanfaatan data penginderaan jauh sebagai bahan dalam mengestimasi kerapatan ekosistem mangrove umumnya menggunakan citra Landsat-TM. Resolusi spasial citra tersebut tergolong rendah. Penggunaan citra dengan resolusi spasial tinggi dalam mengestimasi kondisi ekosistem mangrove dapat menghasilkan data yang lebih detil (Ni-Meister et al., 2010). Sentinel-2A merupkan salah satu citra satelit yang memiliki resolusi spasial tinggi. Citra ini merupakan citra multi-spektral dengan tiga belas saluran berbeda yang memiliki resolusi spasial sebesar 10 meter (ESA, 2015).

Mengestimasi nilai kerapatan mangrove dengan data satelit perlu menggunakan indeks vegetasi untuk menghitung pantulan nilai hijau dari vegetasi mangrove itu sendiri (Muhsoni et al., 2018a). Indeks vegetasi dianalisa berdasarkan nilai-nilai kecerahan digital dari setiap band yang digunakan (Campbell, 2011). Penggunaan indeks vegetasi yang berbeda memiliki hasil nilai vegetasi yang berbeda pula. Oleh karena itu dalam penelitian ini menggunakan perbandingan dari beberapa indeks vegetasi berbeda yaitu NDVI (Normalized Difference Vegetation Index), NNIR (Normalized Near Infrared), EVI (Enhanced Vegetation Index), mRE-SR (Modified Red Edge-Simple Ratio), dan indeks vegetasi yang dikembangkan pada penelitian ini. Indeks vegetasi yang digunakan dipilih berdasarkan hasil terbaik dari penelitianpenelitian sebelumnya yang telah dilakukan (Muhsoni et al., 2018a; Muhsoni et al., 2018b; Pratama et al., 2019; Frananda et al., 2015). Pada penelitian ini juga dilakukan uji statistika yang mengukur signifikansi perbedaan nilai estimasi yang dihasilkan beberapa indeks vegetasi terhadap persentase kerapatan mangrove hasil perhitungan data lapangan.

Penelitian ini bertujuan untuk mengetahui indeks vegetasi dengan akurasi terbaik dalam mengestimasi kondisi kerapatan mangrove. Penelitian ini juga memetakkan distribusi spasial kerapatan mangrove di kawasan TNBB. Diharapkan hasil dari penelitian ini dapat digunakan sebagai salah satu bahan pertimbangan dalam pengambilan kebijakan pengelolaan hutan mangrove di kawasan TNBB, dan juga sebagai referensi untuk penelitian lebih lanjut.

\section{Metodelogi}

\subsection{Lokasi dan Waktu Penelitian}

Penelitian ini berlokasi di kawasan mangrove TNBB. Secara administrasi pemerintahan, kawasan TNBB terletak dalam dua kabupaten yaitu Kabupaten Buleleng dan Jembrana, Propinsi Bali. Sementara itu, secara geografis daerah penelitian terletak antara $8^{\circ} 05^{\prime} 20^{\prime \prime}$ sampai dengan $8^{\circ} 15^{\prime} 25^{\prime \prime}$ LS dan $114^{\circ} 25^{\prime} 00^{\prime \prime}$ sampai dengan $114^{\circ} 56^{\prime} 30^{\prime \prime}$ BT (Balai Taman Nasional Bali Barat, 2018). Pengambilan data lapangan dilakukan pada bulan Januari hingga Februari 2020. Data satelit yang digunakan adalah rekaman data pada tanggal 23 Oktober 2019. Kegiatan pengolahan data dilaksanakan di Laboratorium Remote Sensing dan GIS, Fakultas Kelautan dan Perikanan Universitas Udayana. Peta lokasi penelitian ditampilkan pada Gambar 1.

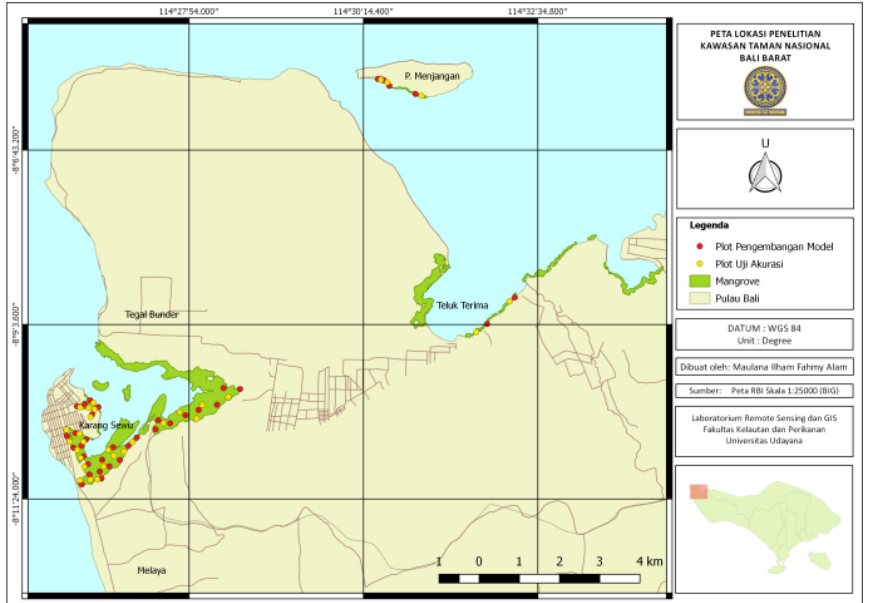

Gambar 1. Peta Lokasi Penelitian di Kawasan TNBB

\subsection{Bahan dan Alat}

Bahan yang digunakan dalam penelitian ini adalah citra Sentinel-2A level 1C (band 2, band 3, band 4, band 5, dan band 8) dengan tanggal akuisisi 23 Oktober 2019, Peta Rupabumi Indonesia skala 1:25000, indeks vegetasi (NDVI, NNIR, EVI, dan mRE-SR), dan hutan mangrove di kawasan TNBB. Untuk pengambilan data lapangan menggunakan beberapa alat seperti GPS, roll meter, kamera digital, buku catatan, dan alat tulis. Sementara itu, alat yang digunakan untuk mengolah data adalah komputer dengan software QGIS, SAGA GIS, Image J, dan Microsoft Exel.

\subsection{Tahap Penelitian}

\subsubsection{Pra Pengolahan Citra}

Pra pengolahan citra merupakan proses awal yang perlu dilakukan dalam pengolahan citra satelit. Tahapan pra pengolahan citra yang dilakukan antara lain koreksi atmosferik, pemotongan citra, dan resampling citra. Koreksi atmosferik berfungsi untuk memperjelas kenampakan pada citra sehingga memudahkan untuk mengenali obyek. Metode koreksi atmosferik pada penelitian ini menggunakan Dark Object Subtraction (DOS), dimana sejumlah piksel disampel dari area deep water sebagai objek paling gelap dari gambar kemudian nilai rerata di setiap band digunakan untuk mengurangi semua piksel lainnya di masing-masing band (Suyarso et al., 2011). Pemotongan citra digunakan untuk memperkecil scene dari citra menjadi seluas daerah penelitian. Tujuan dari pemotongan citra adalah untuk memperkecil ukuran file yang akan diolah sehingga mempercepat proses pengolahan pada software. Hasil pemotongan citra pada daerah penelitian dapat dilihat pada Gambar 2. Resampling pada citra digunakan untuk membuat citra versi baru dengan resolusi spasial berbeda (Shofiyati, 2010). Dalam penelitian ini digunakan untuk membuat resolusi spasial baru dari band RedEdge yang awalnya 20 meter menjadi 10 meter sesuai dengan resolusi spasial utama yang digunakan pada transformasi indeks mRE-SR. 


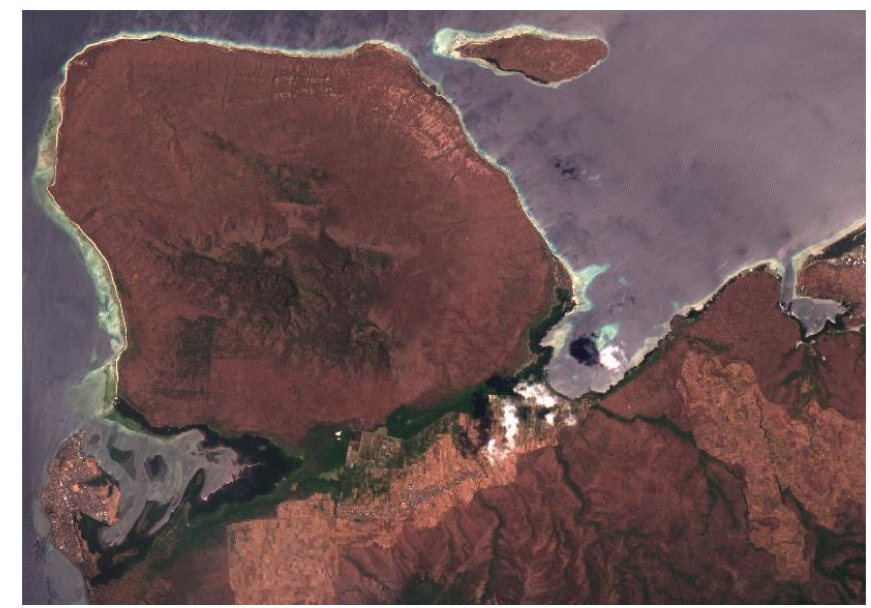

Gambar 2. Kenampakan citra pada daerah penelitian

\subsubsection{Pengolahan Citra}

Citra Sentinel-2A yang sudah dikoreksi kemudian diolah dengan melakukan penyusunan citra komposit menggunakan kombinasi RGB 432 (band red, band green, dan band blue) sehingga menampilkan obyek sebagaimana warna aslinya, seperti yang ditampilkan pada Gambar 2. Kemudian dilakukan masking pada citra yang bertujuan untuk memisahkan antara kawasan mangrove sebagai objek kajian dengan objek lain yang tidak termasuk dalam kajian. Proses masking dilakukan dengan mengubah nilai digital pada objek yang bukan wilayah kajian menjadi nol menggunakan shapefile peta sebaran mangrove di TNBB dari hasil komposit citra dengan tetap mengacu pada peta sebaran mangrove yang didapat dari Balai TNBB. Selanjutnya dilakukan transformasi spektral pada citra. Persamaan transformasi spektral yang digunakan dari beberapa indeks vegetasi ditampilkan pada persamaan (1), (2), (3), dan (4). Sedangkan untuk persamaan indeks vegetasi yang dikembangkan akan ditampilkan pada hasil dan pembahasan.

Indeks vegetasi yang dikembangkan menggunakan kombinasi band near infrared, visible red, dan visible green. Pemilihan ketiga band tersebut didasarkan pada kegunaan masing-masing dari band, dimana band near infrared memiliki kegunaan dalam studi yang berkaitan dengan vegetasi, sedangkan band visible red berguna dalam membedakan objek tanah dengan vegetasi (ESA 2015). Pada vegetasi terjadi proses penyerapan cahaya visible red dan pemantulan cahaya near infrared yang terjadi di daun (Sudiana, 2008). Disamping itu peneliti juga menambahkan unsur band visible green dikarenakan band tersebut memiliki fungsi dalam menilai vegetasi di laut, darat, dan sedimen, serta memiliki panjang gelombang elektromagnetik yang lebih kecil sehingga lebih sensitif terhadap keberadaan objek yang direkam (ESA, 2015). Persamaan indeks vegetasi NDVI, NNIR, EVI, dan mRE-SR disajikan pada persamaan berikut.

$$
N D V I=\frac{(N I R-R e d)}{(N I R+R e d)}
$$

NDVI adalah Normalized Difference Vegetation Index, NIR adalah saluran inframerah dekat (band 8 pada citra Sentinel2A), dan red adalah saluran merah (band 4 pada citra Sentinel2A) (Rouse et al., 1973).

$$
\text { NNIR }=\frac{\text { NIR }}{(\text { NIR }+ \text { Red }+ \text { Green })}
$$

NNIR adalah Normalized Near Infrared, NIR adalah saluran inframerah dekat (band 8 pada citra Sentinel-2A), red adalah saluran merah (band 4 pada citra Sentinel-2A), dan green adalah saluran hijau (band 3 pada citra Sentinel-2A).

$$
=G \frac{(\text { NIR }- \text { Red })}{(\text { NIR }+ \text { C1 } \cdot \text { Red }- \text { C2 } \cdot \text { Blue }+L}
$$

EVI adalah Enhanced Vegetation Index, red adalah saluran merah (band 4 pada citra Sentinel-2A), blue adalah saluran biru (band 2 pada citra Sentinel-2A), C1 dan C2 merupakan koefisien resistansi aerosol pada band merah dan biru dengan nilai ketetapan 6 dan 7.5, G adalah faktor gain dengan nilai ketetapan 2.5, serta L merupakan soil-adjustment factor dengan nilai 1 (Jensen, 2012).

$m R E-S R=\frac{\left(\frac{N I R}{\text { Red Edge }}\right)-1}{\sqrt{\left(\frac{\text { NIR }}{\text { Red Edge }}\right)}+1}$

mRE-SR adalah Modified Red Edge-Simple Ratio, NIR adalah saluran inframerah dekat (band 8 pada citra Sentinel 2A), dan red edge adalah saluran merah tepi (band 5 pada citra Sentinel2A) (Zhu et al., 2017).

\subsubsection{Pengambilan Data Lapangan}

Penentuan sampel di lapangan menggunakan metode stratified random dan proporsional sampling dengan mengacu pada luas area setiap kawasan mangrove yang akan di sampling dan tetap mempertimbangkan keamanan serta keterjangkauan di lapangan (BIG, 2014). Jumlah titik sampel minimal yang harus diambil di lapangan berdasarkan pedoman teknis data geospasial mangrove (BIG, 2014) dapat dilihat pada Tabel 1 .

Tabel 1. Jumlah Titik Sampel Berdasarkan Skala Peta

\begin{tabular}{lcc}
\hline Skala & Minimal Plot & Total Sampel Minimal \\
\hline $1: 25.000$ & 30 & 50 \\
$1: 50.000$ & 20 & 30 \\
$1: 250000$ & 10 & 20 \\
\hline
\end{tabular}

Pada penelitian ini mengambil total sampel plot sebanyak enam puluh enam plot, dengan total sampel foto sebanyak 264 foto. Dimana sebanyak tiga puluh enam sampel plot digunakan untuk membangun model, dan tiga puluh sampel plot lainnya digunakan untuk uji akurasi. Distribusi titik sampel plot ditampilkan pada Gambar 1 .

Penelitian ini menggunakan sampel plot berukuran $10 \mathrm{~m} x$ $10 \mathrm{~m}$ yang dibagi menjadi 4 kuadran plot dimana pada setiap kuadran dilakukan pengambilan data kerapatan tajuk. Desain sampel plot ditampilkan pada Gambar 3. Pengukuran kerapatan tajuk mangrove di lapangan menggunakan metode hemispherical photography, yaitu mengambil foto vertikal dengan sudut pandang $180^{\circ}$ menghadap langit menggunakan kamera berlensa Wide atau Fish Eye. Titik pengambilan foto berada di sekitar pusat kuadran plot dan harus diantara satu pohon dengan pohon lainnya, serta hindarkan pengambilan foto tepat disisi batang satu pohon ataupun pengambilan foto pada kondisi cahaya berlebih (siang) dan cahaya yang minim (senja) karena akan mempengaruhi hasil tutupan yang diperoleh pada foto. Posisi kamera saat pengambilan foto 
diusahakan sejajar dengan tinggi dada peneliti (Dharmawan dan Pramudji, 2014).

Foto yang diperoleh kemudian diolah menjadi Image 8 bit menggunakan software Image $\mathrm{J}$ dengan nilai maksimum piksel adalah 255. Kenampakan salah satu sampel foto dapat dilihat pada Gambar 4. Piksel dengan nilai maksmimum (P255) merupakan piksel yang menggambarkan tutupan mangrove. Konsep pada analisis ini adalah dengan memisahkan piksel langit dan piksel tutupan vegetasi, sehingga persentase jumlah piksel tutupan vegetasi mangrove dapat dihitung dalam analisis gambar biner (Chianucci et al., 2014). Persentase kerapatan tajuk menurut Dharmawan dan Pramudji (2014) dapat dihitung menggunakan persamaan (5).

Persentase Kerapatan Tajuk $=$ P255 / $\sum$ P x 100\%

Dimana P255 merupakan piksel yang menggambarkan tutupan mangrove dan $\sum \mathrm{P}$ merupakan jumlah seluruh piksel.

Nilai di empat titik pengambilan gambar pada satu plot dijumlahkan dan dihitung menjadi satu sehingga dihasilkan nilai persentase kerapatan mangrove per plot.

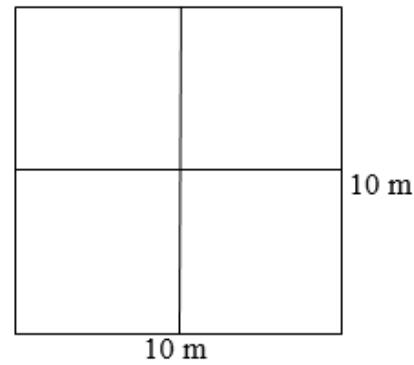

Gambar 3. Desain Sampel Plot Lapangan

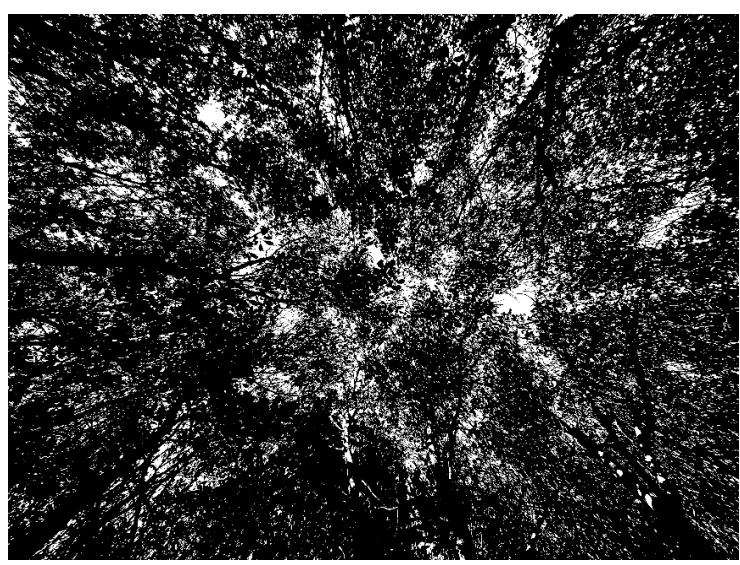

Gambar 4. Salah satu kenampakan sampel foto lapangan 8 bit

\subsection{Analisis Data}

Persamaan regresi linier yang didapat pada masing-masing indeks vegetasi digunakan untuk mengubah nilai indeks vegetasi menjadi estimasi kerapatan mangrove. Data kerapatan mangrove hasil pengolahan citra dengan lima indeks vegetasi berbeda dan hasil pengolahan data lapangan dianalisis untuk mengetahui hubungannya sehingga dapat dilakukan pemilihan indeks vegetasi terbaik yang mampu mengestimasi distribusi spasial kerapatan mangrove di kawasan TNBB. Nilai persentase kerapatan yang didapat berdasarkan indeks vegetasi terbaik selanjutnya diklasifikasikan untuk menggambarkan status kondisi hutan mangrove di kawasan TNBB berdasarkan Keputusan Menteri Lingkungan Hidup No. 201 Tahun 2004 yang ditampilkan pada Tabel 2.

Tabel 2. Kriteria Kondisi Kerapatan Mangrove

\begin{tabular}{llc}
\hline & Kriteria & Penutupan / Kerapatan \\
\hline Baik & Padat & $>75 \%$ \\
& Sedang & $50-75 \%$ \\
Rusak & Jarang & $<50 \%$ \\
\hline
\end{tabular}

Pada penelitian ini dilakukan analisis data untuk mengetahui indeks vegetasi terbaik. Analisis data yang digunakan antara lain analisis regresi, uji koefisien determinasi, uji validasi model, serta uji t berpasangan.

\subsubsection{Analisis Regresi}

Analisis regresi digunakan untuk mengukur ada atau tidaknya korelasi atau hubungan antar variabelnya (Mairing, 2017). Analisis regresi pada penelitian ini digunakan untuk mengetahui besarnya hubungan indeks vegetasi (nilai variabel bebas $\mathrm{x}$ ) terhadap nilai persentase kerapatan mangrove di lapangan (nilai variabel terikat y). Persamaan analisis regresi yang digunakan adalah sebagai berikut:

$Y=a+b X$

$b=\frac{n\left(\sum x y\right)-\left(\sum x\right) \cdot\left(\sum y\right)}{n\left(\sum x^{2}\right)-\left(\sum x\right)^{2}}$

$a=\frac{\Sigma y-b \cdot\left(\sum x\right)}{n}$

Dimana $Y$ adalah variabel terikat (persentase kerapatan tajuk), $x$ adalah variabel bebas (nilai indeks vegetasi), $a$ adalah konstanta, $b$ adalah koefisien regresi, dan $n$ adalah jumlah data.

\subsubsection{Uji Koefisien Determinasi}

Koefisien determinasi $\left(\mathrm{R}^{2}\right)$ digunakan untuk mengukur seberapa jauh kemampuan variabel bebas (indeks vegetasi) dalam menerangkan variasi variabel terikat (kerapatan mangrove di lapangan). Nilai $\mathrm{R}^{2}$ berkisar antara nol sampai dengan satu. Nilai $\mathrm{R}^{2}$ yang kecil atau mendekati nol berarti menunjukkan kemampuan variabel bebas dalam menjelaskan variasi variabel terikat sangat terbatas. Sebaliknya, nilai yang tinggi atau mendekati satu menunjukkan variabel bebas dapat memberikan hampir semua informasi yang dibutuhkan untuk memprediksi variasi variabel terikat. Adapun rumus untuk menghitung nilai koefisien determinasi adalah sebagai berikut (Mairing, 2017).

$$
R^{2}=\frac{\left((n)\left(\sum x y\right)-\left(\sum x\right)\left(\sum y\right)\right)^{2}}{\left(n\left(\sum x^{2}\right)-\left(\sum x\right)^{2}\left(n\left(\sum y^{2}\right)-\left(\sum y\right)^{2}\right)\right)}
$$

dimana $y$ adalah variabel terikat (nilai kerapatan tajuk); $x$ adalah variabel bebas (nilai indeks vegetasi); dan $n$ adalah jumlah data.

\subsubsection{Uji Validasi Model}

Uji validasi model pada penelitian ini menggunakan standard error (SE) untuk mengetahui seberapa besar 
penyimpangan yang terjadi pada hasil perhitungan dari model terhadap nilai aktual. Semakin kecil nilai SE yang dihasilkan menunjukkan semakin kecil pula penyimpangan yang terjadi pada hasil perhitungan model suatu indeks vegetasi terhadap nilai kerapatan mangrove di lapangan. Perhitungan SE menurut Mairing (2017) dapat dilihat pada persamaan (10).

$S E=\frac{S D}{\sqrt{n}}$

dimana $S D$ adalah standar deviasi; dan $n$ adalah jumlah sampel.

\subsubsection{Uji t Berpasangan}

Data kerapatan mangrove di lapangan yang akan digunakan dalam uji t berpasangan, diuji normalitas distribusi sampelnya terlebih dahulu. Uji normalitas menggunakan metode Kolmogorov-Smirnov. Uji normalitas data ini bertujuan untuk mengetahui apakah sampel yang digunakan berdistribusi normal atau tidak.

Uji t berpasangan (paired t-test) adalah salah satu metode uji hipotesis dengan menggunakan data berpasangan. Data berpasangan yang dimaksud yaitu data objek penelitian diberikan dua perlakuan berbeda sehingga didapatkan dua macam sampel dari masing-masing perlakuan (Kurniawan 2008). Uji t berpasangan pada penelitian ini bertujuan untuk menganalisis nilai kerapatan mangrove berdasarkan data lapangan dan data kerapatan mangrove hasil dari perhitungan model. Persamaan uji t berpasangan adalah sebagai berikut:

thitung $=\frac{D}{S D / \sqrt{n}}$

dimana $D$ adalah rerata selisih pengukuran data 1 dan 2 ; serta $S D$ adalah standar deviasi selisih pengukuran data 1 dan 2 .

Kriteria uji t berpasangan yang digunakan pada penelitian ini adalah sebagai berikut:

1. Jika nilai t hitung $\leq$ nilai t tabel, maka $H O$ diterima, sehingga nilai kerapatan mangrove hasil perhitungan model tidak berbeda nyata dengan nilai kerapatan mangrove hasil perhitungan lapangan.

2. Jika nilai t hitung > nilai t tabel, maka $H 1$ diterima, sehingga nilai kerapatan mangrove hasil perhitungan model berbeda nyata dengan nilai kerapatan mangrove hasil perhitungan lapangan.

\section{Hasil dan Pembahasan}

\subsection{Nilai Spektral Mangrove pada Beberapa Indeks Vegetasi}

Salah satu dari lima indeks vegetasi yang digunakan merupakan indeks vegetasi baru yang dikembangkan pada penelitian ini dengan nama Normalized Green Vegetation Index (NGVI). Persamaan NGVI yang dihasilkan adalah sebagai berikut:

$N G V I=\frac{(\text { NIR }- \text { Red }- \text { Green })}{(\text { NIR }+ \text { Red }+ \text { Green })}$
Rentang nilai yang dihasilkan setiap indeks vegetasi pada sampel mangrove kawasan TNBB ditampilkan pada Tabel 3.

Tabel 3. Rentang Nilai Spektral Beberapa Indeks Vegetasi

\begin{tabular}{ccccc}
\hline $\begin{array}{c}\text { Indeks } \\
\text { Vegetasi }\end{array}$ & $\begin{array}{c}\text { Nilai } \\
\text { Minimal }\end{array}$ & $\begin{array}{c}\text { Nilai } \\
\text { Maksimal }\end{array}$ & $\begin{array}{c}\text { Rata- } \\
\text { Rata }\end{array}$ & $\begin{array}{c}\text { Standar } \\
\text { Deviasi }\end{array}$ \\
\hline NDVI & 0.259 & 0.682 & 0.524 & 0.097 \\
NNIR & 0.477 & 0.689 & 0.613 & 0.052 \\
EVI & 0.126 & 0.327 & 0.230 & 0.055 \\
mRE-SR & 0.391 & 1.234 & 0.868 & 0.208 \\
NGVI & -0.045 & 0.397 & 0.226 & 0.104 \\
\hline
\end{tabular}

Dari tabel diatas, ditunjukkan bahwa nilai standar deviasi terbesar dihasilkan oleh indeks vegetasi mRE-SR dengan nilai 0.208 , sedangkan nilai standar deviasi terkecil dihasilkan oleh indeks vegetasi NNIR dengan nilai 0.05223. Semakin tinggi nilai standar deviasi yang dihasilkan maka semakin besar variasi sebaran data pada sampel, maka dari itu indeks vegetasi mRE-SR merupakan indeks vegetasi yang memiliki variasi nilai sebaran data sampel terbesar dibandingkan indeks vegetasi lainnya. Berdasarkan nilai minimal dan maksimal setiap indeks vegetasi yang ditampilkan pada Tabel 3 , indeks vegetasi mRE-SR juga memiliki rentang nilai terbesar yaitu 0.391 hingga 1.234. Semakin tinggi nilai standar deviasi pada sampel, maka semakin bervariasi nilai sampel tersebut, sehingga sampel yang dihasilkan semakin baik.

\subsection{Hubungan Kerapatan Mangrove dengan Nilai Indeks Vegetasi}

Nilai spektral masing-masing indeks vegetasi yang digunakan dalam penelitian ini selanjutnya dibandingkan dengan nilai kerapatan tajuk hasil pengolahan data lapangan sebanyak 36 plot sampel untuk mengetahui hubungan antara kedua variabel terebut. Parameter statistik yang digunakan untuk menilai keeratan hubungan kedua variabel tersebut adalah koefisien determinasi dan standard error. Hasil hubungan antara nilai dari kelima indeks vegetasi dengan persentase kerapatan tajuk mangrove di lapangan dapat dilihat pada Gambar 5 dan Tabel 4.

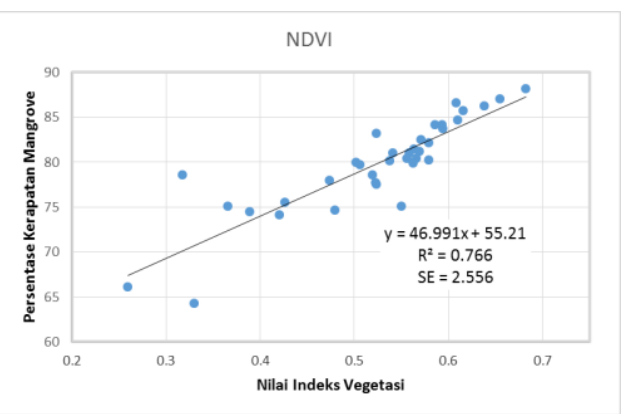

(a) 


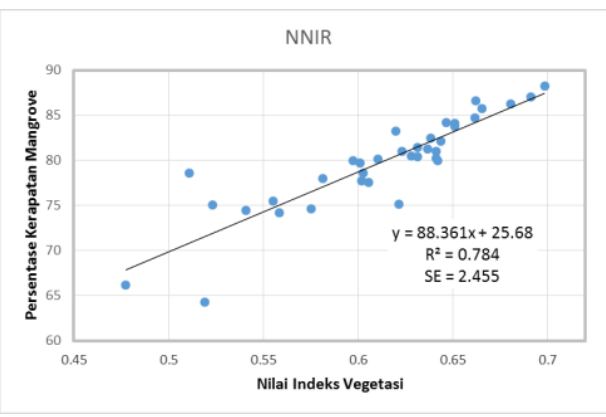

(b)

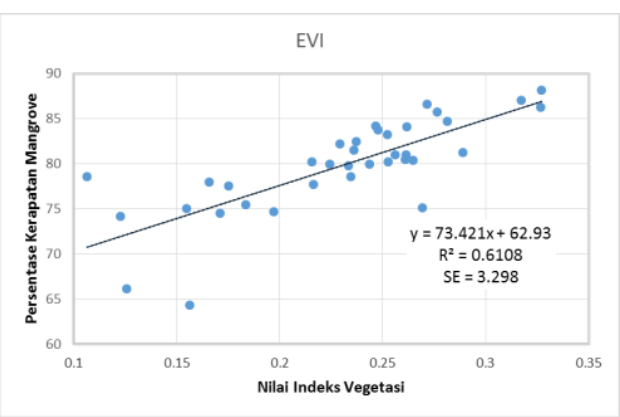

(c)

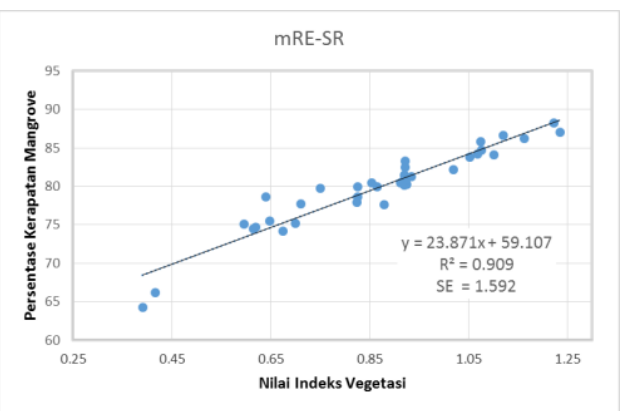

(d)

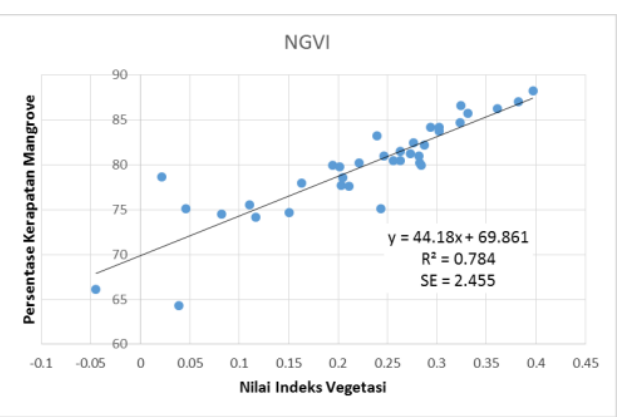

(e)

Gambar 5. Hubungan Setiap Indeks Vegetasi dengan Kerapatan Mangrove, (a) NDVI, (b) NNIR, (c) EVI, (d) mRE-SR, (e) NGVI

Tabel 4. Hubungan Nilai Indeks Vegetasi dengan Persentase Kerapatan Mangrove di Lapangan

\begin{tabular}{cccc}
\hline $\begin{array}{c}\text { Indeks } \\
\text { Vegetasi }\end{array}$ & $\begin{array}{c}\text { Persamaan Regresi } \\
\text { Linear }\end{array}$ & $\mathbf{R}^{2}$ & SE \\
\hline NDVI & $\mathrm{y}=46.991 \mathrm{x}+55.21$ & 0.766 & 2.556 \\
NNIR & $\mathrm{y}=88.361 \mathrm{x}+25.68$ & 0.784 & 2.455 \\
EVI & $\mathrm{y}=73.421 \mathrm{x}+62.93$ & 0.611 & 3.298 \\
mRE-SR & $\mathrm{y}=23.871 \mathrm{x}+59.107$ & 0.909 & 1.592 \\
NGVI & $\mathrm{y}=44.18 \mathrm{x}+69.861$ & 0.784 & 2.455 \\
\hline
\end{tabular}

Hasil analisis regresi dari kelima indeks vegetasi yang digunakan didapat mRE-SR sebagai indeks vegetasi dengan nilai terbaik. Model regresi linier pada indeks vegetasi mRESR memiliki persamaan $\mathrm{y}=23.871 \mathrm{x}+59.107$, dimana $\mathrm{x}$ adalah nilai indeks vegetasi dan y adalah nilai kerapatan mangrove (\%). Nilai koefisien determinasi tertinggi dan standard error terendah juga ditunjukkan oleh indeks vegetasi mRE-SR dengan nilai $\mathrm{R}^{2} 0.909$ dan nilai SE 1.592. Sedangkan indeks vegetasi dengan nilai parameter keeratan terendah adalah EVI, dimana didapat nilai $\mathrm{R}^{2} 0.611$ dan nilai SE 0.055 pada indeks vegetasi tersebut. Semakin tinggi nilai $\mathrm{R}^{2}$ yang didapat maka semakin baik nilai indeks vegetasi dapat menjelaskan variasi nilai kerapatan tajuk dilapangan. Sebaliknya, semakin kecil nilai SE yang diperoleh maka semakin kecil pula penyimpangan yang terjadi pada hubungan kedua variabel tersebut.

\subsection{Uji Ketelitian}

Uji ketelitian dilakukan dengan analisis regresi antara persentase kerapatan mangrove hasil pengukuran di lapangan dengan persentase kerapatan mangrove hasil estimasi menggunakan indeks vegetasi. Sampel yang digunakan pada uji ketelitian ini adalah 30 plot sampel. Semakin tinggi nilai R2 dan semakin rendah nilai SE yang diperoleh dari hubungan linear tersebut, maka semakin tinggi tingkat ketelitian yang didapatkan. Nilai ketelitian yang tinggi menunjukkan adanya keselarasan antara nilai hasil estimasi dengan hasil pengukuran di lapangan. Indeks vegetasi yang menghasilkan uji ketelitian tertinggi merupakan indeks vegetasi terbaik dalam estimasi kerapatan mangrove. Grafik uji ketelitian dari kelima indeks vegetasi ditampilkan pada Gambar 6.

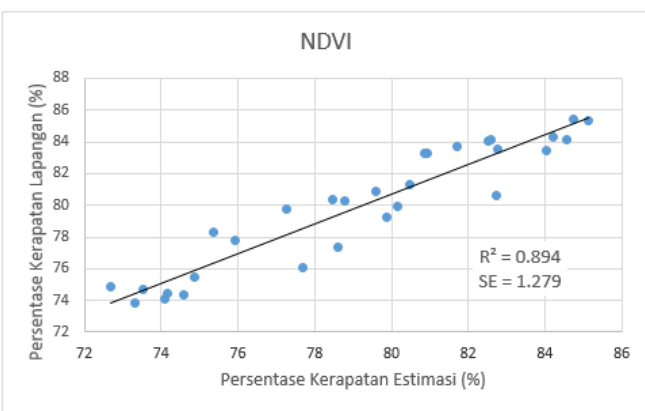

(a)

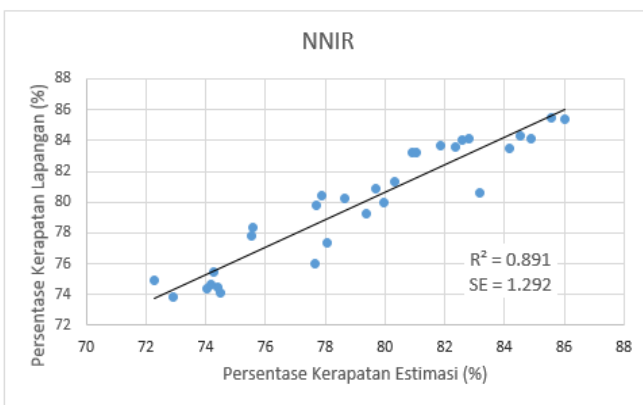

(b) 


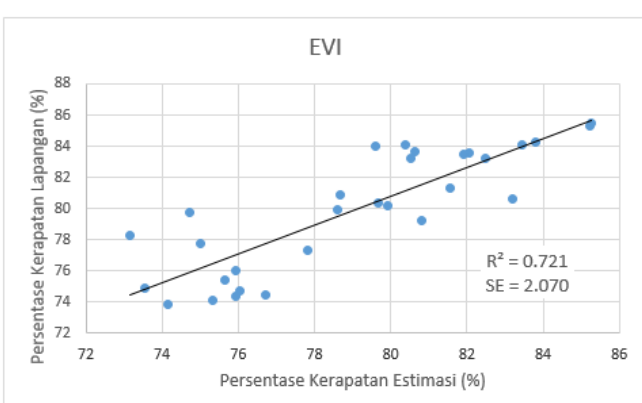

(c)

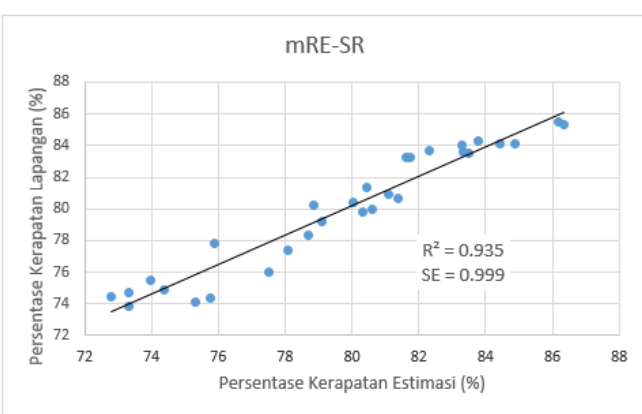

(d)

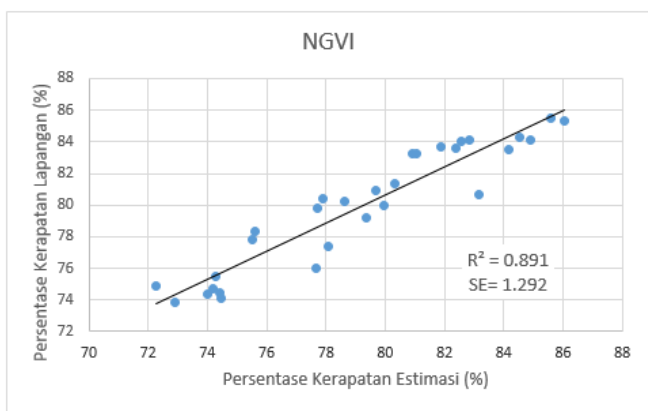

(e)

Gambar 6. Uji Ketelitian Setiap Indeks Vegetasi, (a) NDVI, (b) NNIR, (c) EVI, (d) mRE-SR, (e) NGVI

Pada uji ketelitian ini didapatkan nilai $\mathrm{R}^{2}$ pada indeks vegetasi NDVI, NNIR, EVI, mRE-SR, dan NGVI masingmasing 0.894, 0.891, 0.721, 0.935, dan 0.891. Sementara itu, nilai SE yang didapat dari indeks vegetasi yang sama berturutturut 1.279, 1.292, 2.07, 0.999, dan 1.292. Dari kelima grafik uji ketelitian tersebut, nilai $\mathrm{R}^{2}$ tertinggi dan nilai SE terendah ditunjukkan oleh indeks vegetasi mRE-SR (Gambar 6d). Dengan demikian mRE-SR merupakan indeks vegetasi yang mempunyai tingkat ketelitian tertinggi dalam mengestimasi persentase kerapatan mangrove.

\subsection{Uji t Berpasangan}

Disamping uji ketelitian, uji tingkat signifikansi perbedaan hasil estimasi kerapatan mangrove dengan hasil pengukuran di lapangan perlu dilakukan. Untuk mengetahui hal tersebut, maka dilakukan uji t berpasangan pada penelitian ini. Sebelum dilakukan uji t berpasangan, didahului dengan uji normalitas data. Dari hasil uji normalitas data dengan metode Kolmogorov-Smirnov diperoleh distribusi data sampel adalah normal.

Taraf signifikansi $(\alpha)$ yang digunakan pada uji t berpasangan dalam penelitian ini adalah 0.05 atau $5 \%$, sehingga taraf kepercayaan pada data yang dihasilkan sebesar 95\%. Ringkasan hasil uji t berpasangan ditampilkan pada Tabel 5.

Tabel 5. Hasil Uji t Berpasangan Beberapa Indeks Vegetasi

\begin{tabular}{cccccc}
\hline $\begin{array}{c}\text { Uji t } \\
\text { Berpasangan }\end{array}$ & NDVI & NNIR & EVI & mRE-SR & NGVI \\
\hline t hitung & 3.138 & 2.910 & 2.365 & 1.090 & 2.909 \\
$\begin{array}{c}\mathrm{P}(\mathrm{T}<=\mathrm{t}) \text { two- } \\
\text { tail } \\
\mathrm{t} \text { tabel two- } \\
\text { tail }\end{array}$ & 0.004 & 0.007 & 0.023 & 0.285 & 0.007 \\
\hline
\end{tabular}

Dari hasil uji t berpasangan tersebut, hanya didapatkan satu indeks vegetasi dengan nilai t hitung yang lebih kecil dari nilai t tabel, yaitu indeks vegetasi mRE-SR. Indeks vegetasi ini memiliki nilai t hitung 1.090, sedangkan nilai t tabel adalah 2.045. Hasil tersebut menunjukkan bahwa hipotesis awal atau $\mathrm{HO}$ diterima, sehingga nilai estimasi kerapatan mangrove hasil perhitungan model tidak berbeda nyata dengan nilai kerapatan mangrove di lapangan. Selain itu, juga didapatkan nilai $\mathrm{P}(\mathrm{T}<=\mathrm{t})$ two-tail pada indeks vegetasi ini sebesar 0.285 , nilai tersebut lebih besar dari nilai taraf signifikansi $(\alpha)$ yaitu 0.05 yang berarti kedua nilai yang diuji tidak berbeda nyata, sehingga hipotesis awal diperkuat.

\subsection{Pemilihan Indeks Vegetasi Terbaik}

Pemilihan indeks vegetasi terbaik yang mampu mengestimasi persentase kerapatan mangrove di kawasan TNBB didasarkan pada hubungan kerapatan mangrove dengan nilai indeks vegetasi, hasil uji ketelitian, dan hasil uji $t$ berpasangan. Perbandingan nilai beberapa parameter akurasi yang dihasilkan dari setiap indeks vegetasi ditampilkan pada Tabel 6.

Tabel 6. Nilai Beberapa Parameter Indeks Vegetasi

\begin{tabular}{lccccc}
\hline $\begin{array}{c}\text { Indeks } \\
\text { Vegetasi }\end{array}$ & $\mathbf{R}^{2}{ }^{1)}$ & SE $^{1)}$ & $\mathbf{R}^{2}{ }^{2)}$ & $\mathbf{S E}^{2)}$ & $\begin{array}{c}\mathbf{P}(\mathbf{T}<=\mathbf{t}) \\
\text { two-tail }\end{array}$ \\
\hline NDVI & 0.766 & 2.556 & 0.894 & 1.279 & 0.004 \\
NNIR & 0.784 & 2.455 & 0.891 & 1.292 & 0.007 \\
EVI & 0.611 & 3.298 & 0.721 & 2.070 & 0.023 \\
mRE-SR & 0.909 & 1.592 & 0.935 & 0.999 & 0.285 \\
NGVI & 0.784 & 2.455 & 0.891 & 1.292 & 0.007 \\
\hline
\end{tabular}

1) $\mathrm{R}^{2}$ dan SE dari hubungan antara nilai indeks vegetasi dengan persentase kerapatan mangrove hasil perhitungan di lapangan.

2) $\mathrm{R}^{2}$ dan $\mathrm{SE}$ dari hubungan antara persentase kerapatan mangrove hasil estimasi indeks vegetasi dengan hasil perhitungan di lapangan.

Berdasarkan hasil analisis statistik pada Tabel 6, mRE-SR merupakan indeks vegetasi yang memiliki akurasi terbaik dalam memetakan kondisi kerapatan mangrove di kawasan TNBB. Hasil ini serupa dengan penelitian Pratama (2019) menggunakan citra Sentinel-2A yang menunjukkan bahwa mRE-SR sebagai indeks vegetasi terbaik dalam mengestimasi kerapatan mangrove di kawasan TAHURA Ngurah Rai. Menurut Zhu et al. (2017), tingkat akurasi yang tinggi pada indeks vegetasi mRE-SR ini dikarenakan keunggulan pada band red edge yang digunakan, dimana band red edge memiliki sensitifitas yang lebih baik terhadap parameter 
biofisik vegetasi seperti biomassa dibandingkan dengan band lainnya. Band red edge dapat mengurangi masalah kejenuhan sampai batas tertentu di area mangrove sehingga mampu meningkatkan akurasi indeks vegetasi tersebut.

Distribusi spasial kerapatan tajuk mangrove di TNBB hasil perhitungan model mRE-SR sebagai indeks vegetasi terbaik memiliki nilai sebaran persentase mangrove dengan rentang $57.952 \%$ hingga $99.265 \%$. Nilai persentase kerapatan mangrove yang didapat selanjutnya diklasifikasi berdasarkan Tabel 2 untuk menggambarkan status kondisi hutan mangrove. Hasil klasifikasi nilai persentase mangrove dapat dilihat pada Tabel 7. Sementara itu, peta distribusi spasial kerapatan tajuk mangrove di TNBB dapat dilihat pada Gambar 7.

Tabel 7. Hasil Klasifikasi Katagori Kerapatan Mangrove

\begin{tabular}{llccc}
\hline $\begin{array}{l}\text { Katagori } \\
\text { Kerapatan }\end{array}$ & $\begin{array}{c}\text { Persentase } \\
\text { Kerapatan } \\
(\%)\end{array}$ & $\begin{array}{c}\text { Jumlah } \\
\text { Piksel }\end{array}$ & $\begin{array}{c}\text { Luas } \\
\text { Area } \\
(\mathbf{m} 2)\end{array}$ & $\begin{array}{c}\text { Luas } \\
\text { Area } \\
(\text { Ha) }\end{array}$ \\
\hline Sedang & $50-75$ & 11963 & 1196300 & 119.63 \\
Padat & $>75$ & 28958 & 2895800 & 289.58 \\
\hline Total & & 40921 & 4092100 & 409.21 \\
\hline
\end{tabular}

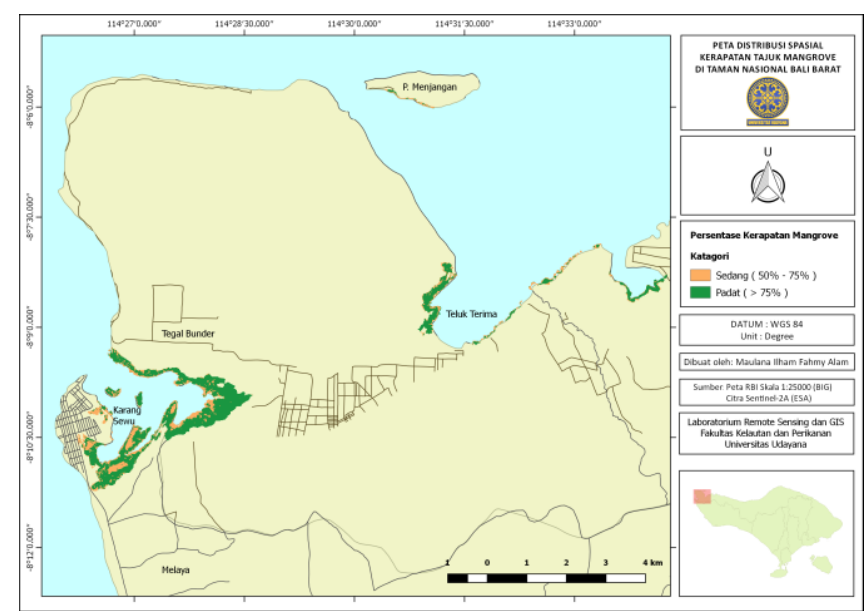

Gambar 7. Peta distribusi spasial kerapatan mangrove di TNBB

Peta distribusi spasial kerapatan tajuk magrove yang lebih jelas ditampilkan pada Gambar 8, 9, dan 10. Hal tersebut dikarenakan kawasan mangrove di TNBB memiliki beberapa bagian yang tersebar secara terpisah.

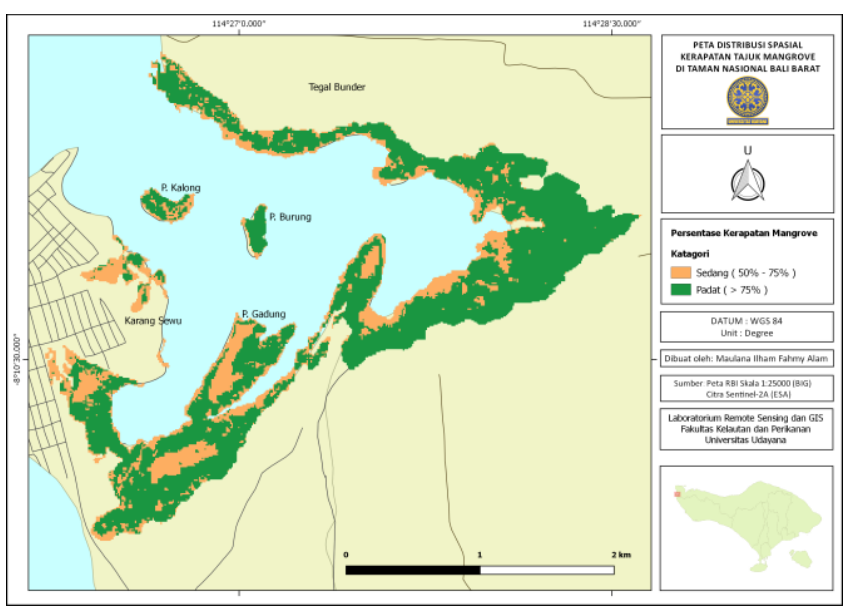

Gambar 8. Peta distribusi spasial kerapatan mangrove di TNBB bagian barat

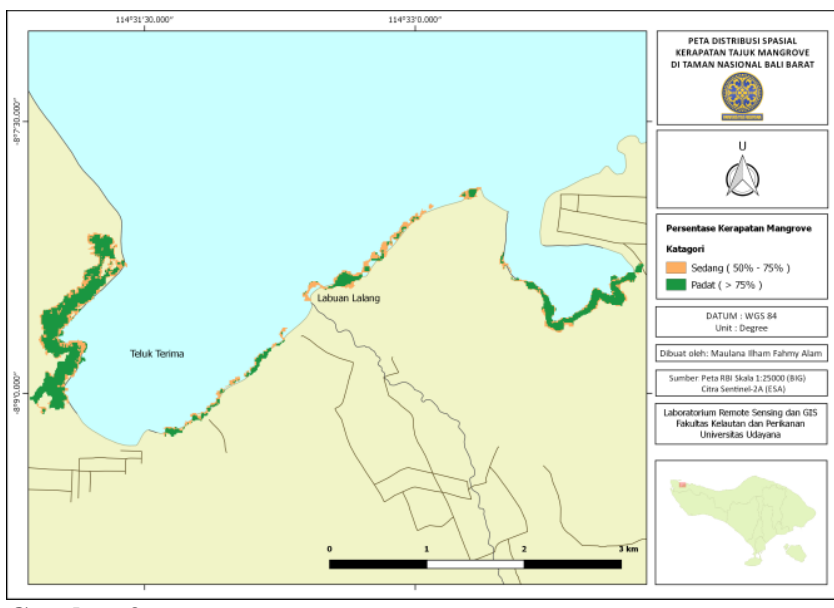

Gambar 9. Peta distribusi spasial kerapatan mangrove di TNBB bagian timur

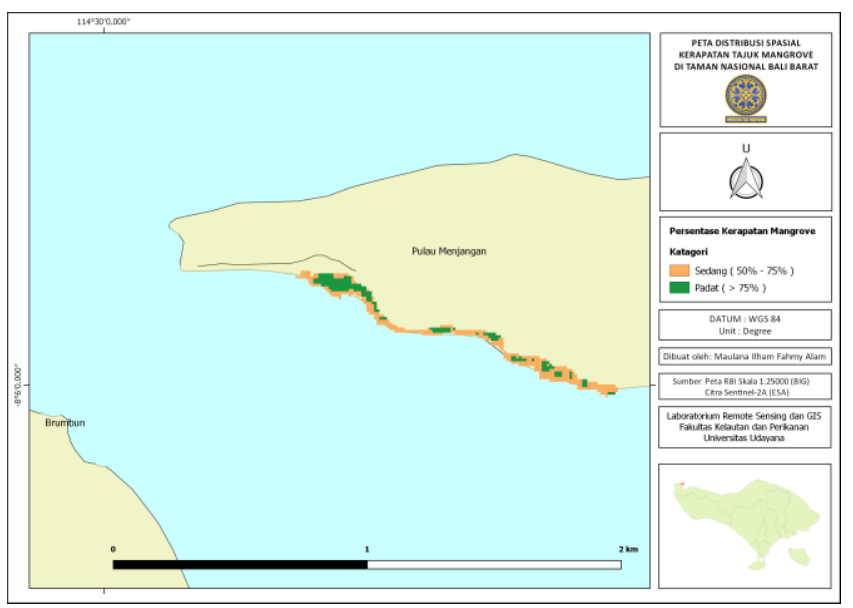

Gambar 10. Peta distribusi spasial kerapatan mangrove di Pulau Menjangan

Hasil perhitungan menunjukkan bahwa total luas mangrove TNBB pada daerah penelitian adalah 409.21 ha. Hasil tersebut berbeda dengan luas kawasan mangrove TNBB tahun 2016 menurut Balai Taman Nasional Bali Barat yaitu sekitar 512 ha (Balai Taman Nasional Bali Barat, 2018). Perbedaan hasil luas yang diperoleh disebabkan terdapat beberapa kawasan mangrove TNBB yang tidak termasuk dalam daerah penelitian dikarenakan memiliki area kawasan yang relatif sempit dan tersebar di beberapa bagian.

Dari persentase kerapatan yang didapat, kelas kerapatan mangrove hanya terdistribusi pada kelas kerapatan sedang dan padat. Berdasarkan peta distribusi kerapatan tajuk mangrove yang dihasilkan, kondisi kerapatan tajuk mangrove di daerah penelitian didominasi oleh katagori kerapatan tajuk padat dengan luas area mencapai 289.58 ha atau $70.77 \%$ dari luas keseluruhan daerah penelitian. Sedangkan untuk katagori kerapatan sedang memiliki luas 119.63 ha atau $29.34 \%$. Mengacu pada Keputusan Menteri Lingkungan Hidup No. 201 tahun 2004 mengenai kriteria kondisi mangrove yang ditampilkan pada Tabel 2, hasil keseluruhan distribusi spasial kerapatan tajuk mangrove di daerah penelitian terbilang sangat baik dengan tidak adanya mangrove yang termasuk dalam katagori rusak. Hal tersebut dikarenakan daerah mangrove yang diteliti berada di dalam kawasan taman nasional, dimana kawasan tersebut merupakan objek konservasi sehingga kelestariannya terjaga dengan baik (Balai Taman Nasional Bali Barat, 2018). 


\section{Kesimpulan}

Berdasarkan hasil yang diperoleh dari penelitian ini, maka didapat kesimpulan sebagai berikut:

1. Indeks mRE-SR merupakan indeks vegetasi terbaik dalam memetakan kerapatan mangrove karena memiliki nilai akurasi terbaik di keseluruhan parameter statistik yang diuji. Hasil uji t berpasangan juga menun-jukkan bahwa tidak ada perbedaan yang nyata antara kerapatan tajuk mangrove hasil pengukuran di lapangan dengan kerapatan mangrove hasil estimasi dengan indeks vegetasi mRE-SR.

2. Distribusi kerapatan mangrove yang dihasilkan menunjukkan bahwa kawasan mangrove di daerah penelitian memiliki rentang nilai kerapatan $57.952 \%$ hingga $99.265 \%$ yang tergolong dalam dua kelas kerapatan yaitu sedang dan padat. Mangrove di daerah penelitian didominasi oleh katagori kerapatan tajuk padat dengan luas 289.58 ha $(70.77 \%)$ dari luas keseluruhan mangrove (409.21 ha).

\section{Daftar Pustaka}

Andriani I, Mey D, Saleh F. 2017. Pemetaan Hutan Mangrove Dengan Menggunakan Analisis Transformasi Indeks Di Kawasan Taman Nasional Rawa Aopa Watumohai Provinsi Sulawesi Tenggara. Jurnal Geografi Aplikasi Dan Teknologi Vol. 1 (2) : 45 - 52

Badan Informasi Geospasial. 2014. Pedoman Teknis Pengumpulan dan Pengolahan Data Geospasial Mangrove. Cibinong. $47 \mathrm{hlm}$

Balai Riset dan Observasi Laut. 2017. Serbuan Sampah di Hutan Mangrove Pulau Menjangan. http://www.bpol.litbang.kkp.go.id/25berita-terkini/197-serbuan-sampah-di-hutan-mangrove-pulaumenjangan. [15 Oktober 2019]

Balai Taman Nasional Bali Barat. 2018. Ekosistem Mangrove di Taman Nasional Bali Barat. Bali : Direktorat Jendral Konservasi Sumber Daya Alam dan Ekosistem, Kementerian Lingkungan Hidup dan Kehutanan.

Campbell JB, Wynne RH. 2011. Introduction To Remote Sensing - Fifth Edition. New York : Guilford Press. $667 \mathrm{hlm}$

Chianucci F, Chiavetta U, Cutini A. 2014. The Estimation of Canopy Attributes from Digital Cover Photography by Two Different Image Analysis Methods. iForest, Vol.7 : 255 - 259

Dharmawan IWE, Pradmuji. 2014. Panduan Monitoring Status Kesehatan Komunitas Mangrove. Jakarta : COREMAP CTI LIPI. $35 \mathrm{hlm}$

Direktorat Jendral Konservasi Sumber Daya Alam dan Ekosistem. 2018. Koordinasi Parapihak Pengendalian Sampah di TN Bali Barat. Kementerian Lingkungan Hidup dan Kehutanan. http://ksdae.menlhk.go.id/info/2467/koordinasi-parapihakpengendalian-sampah-di-tn-bali-barat.html. [15 Oktober 2019]

Europan Space Agency. 2015. Sentinel-2 User Handbook (Issue 1 Rev 2). Paris (FR): ESA Standart Document. $64 \mathrm{hlm}$

Frananda H, Hartono, Jatmiko RH. 2015. Komparasi Indeks Vegetasi Untuk Estimasi Stok Karbon Hutan Mangrove Kawasan Segoro Anak Pada Kawasan Taman Nasional Alas Purwo Banyuwangi, Jawa Timur. Majalah Ilmiah Globë, Volume 17 (2) : 113 - 123

Jensen RR, Hardin PJ, Hardin AJ. 2012. Estimating Urban Leaf Area Index (LAI) Of Individual Trees With Hyperspectral Data. Photogrammetric Engineering \& Remote Sensing. Vol 78 (5) : 495 $-504$
Kawamuna A, Suprayogi A, Wijaya AP. 2017. Analisis Kesehatan Hutan Mangrove Berdasarkan Metode Klasifikasi NDVI Pada Citra Sentinel-2 (Studi Kasus: Teluk Pangpang Kabupaten Banyuwangi). Jurnal Geodesi Undip Vol. 6 (1) : 277 - 284

Kementerian Lingkungan Hidup dan Kehutanan. 2017. Miliki 23\% Ekosistem Mangrove Dunia, Indonesia Tuan Rumah Konferensi Internasional Mangrove 2017. Siaran Pers KLHK No : SP. 58/HUMAS/PP/HMS.3/03 /2017. http://ppid.menlhk.go.id/siaran_ pers/browse/561. [23 Oktober 2019]

Kurniawan D. 2008. Uji T Berpasangan (Paired T-Test). Vienna (AT) : Foundation for Statistical Computing.

Mairing JP. 2017. Statistika Pendidikan, Konsep dan Penerapannya Menggunakan Minitab dan Microsoft Excel. Yogyakarta : Penerbit Andi.

Mangrove Information Centre. 2004. Pengertian Dasar Mangrove (Bakau). The Development of Sustainable Mangrove Management Project. Bali : Ministry of Forestry and Estate Crops and JICA.

Muhsoni FF, Sambah AB, Mahmudi M, Wiadnya DGR. 2018a. Comparison of Different Vegetation Indices for Assessing Mangrove Density Using Sentinel-2 Imagery. International Journal of GEOMATE, Vol. 14, Issue $45: 42-51$

Muhsoni FF, Sambah AB, Mahmudi M, Wiadnya DGR. 2018b. Estimation Of Mangrove Carbon Stock With Hybrid Method Using Image Sentinel-2. International Journal of GEOMATE, Vol. 15, Issue 49 : $185-192$

Ni-Meister W, Lee S, Strahler AH, Woodcock CE, Schaaf C, Yao T, Blair JB. 2010. Assessing General Relationships Between Aboveground Biomass and Vegetation Structure Parameters for Improved Carbon Estimate from Lidar Remote Sensing. Journal of Geophysical Research: Biogeosciences, 115(G2) : $1-12$

Pratama IGMY, Karang IWGA, Suteja Y. 2019. Distribusi Spasial Kerapatan Mangrove Menggunakan Citra Sentinel-2A Di TAHURA Ngurah Rai Bali. Journal of Marine and Aquatic Sciences 5(2) : 192-202

Rouse JW, Haas RH, Schell JA, Deering DW. 1973. Monitoring Vegetation Systems in the Great Plains with ERTS. In Proceedings of Third Earth Resources Technology Satellite-1 Symposium. Washington, DC, USA, 10 - 14 December 1973 : 309 - 317

Sari SP, Rosalina D. 2016. Mapping and Monitoring of Mangrove Density Changes on Tin Mining Area. The 2nd International Symposium on LAPAN-IPB Satellite for Food Security and Environmental Monitoring 2015, LISAT-FSEM 2015. Procedia Environmental Sciences 33 (2016) : $436-442$

Shofiyati R, Las I, Agus, F. 2010. Indonesian Soil Database and Predicted Stock of Soil Carbon. In Proceedings of International Workshop on Evaluation and Sustainable Management of Soil Carbon Sequestration in Asian Countries. Bogor : September. hlm 28-29.

Zhu Y, Liu K, Liu L, Myint SW, Wang S, Liu H, He Z. 2017. Exploring the Potential of WorldView-2 Red-Edge Band-Based Vegetation Indices for Estimation of Mangrove Leaf Area Index with Machine Learning Algorithms. Remote Sensing, 9(10) : $1-20$ 